\title{
Biography
}

Geraldine Van de Kleut is a classroom teacher who has taught for fifteen years in Southwestern Ontario, from Junior Kindergarten to Grade Six, as well as a part-time instructor for Mount Saint Vincent University in Halifax. She is presently also a doctoral student at Brock University.

\begin{abstract}
$\underline{\text { Abstract }}$
This paper recounts a controversial incident in a classroom that ultimately involved the student, her teacher, her parents, the school's administrators, government curriculum, and a university professor. Using discourse theory, the author traces the beliefs that underlie the positions taken by the stakeholders, and discusses the vulnerable spaces that teachers inhabit when they practice critical literacy in elementary classrooms using difficult texts and subjects.
\end{abstract}

\section{Getting Out of the Way: Books, Children and Controversy}

\section{GERALDINE VAN DE KLEUT}

\section{Brock University}

My father was a publisher and an editor, and gave many speeches to teachers when I was growing up. He was fiercely devoted to literature, and decried the way teachers stood between books and children. He wanted to sell books, not programs; over and over again he advised the teachers to put the books in the hands of their students. 
The first time I heard my father's phrase, "Give them the books and get out of their way," it was a clarion call. I was newly graduated from high school, and full of resentment over how much in the way my teachers had been. Freedom with books seemed to me to be paradise, and I was convinced that that was how school should be for all children.

That conviction accompanied me when ten years later I entered teacher's college. I was going to be the kind of teacher who opened her vast classroom library to children, and stayed out of the way as they explored wonderful books and changed as a result of them. Children in my class were going to love every day, and when they left they were -all of them -- going to be readers.

It wasn't long before I began to question my vision of teaching. As I moved through the divisions, spending three years teaching kindergarten and four years teaching second grade before moving to a grade five and six classroom, my teaching did not seem to turn out as planned. My students liked me well enough, for the most part, and I did start to acquire that vast library. However, at the end of every year I said goodbye to a few students in each class who obstinately, perfidiously, refused to like reading. I said goodbye to the ones who eschewed the quality, life-enhancing literature I provided, and stuck to a steady diet of bland series texts and anthologies of knock-knock jokes. And even more troubling to me, I said goodbye to the ones who hadn't changed; who despite our many shared texts and conversations about sexism, racism, justice and inclusion took their sexist, racist, unjust and exclusive selves back to the playground and their families.

My teaching was not having the results I expected. I had stepped out of the way of my students' enjoyment of literature. They chose their own books, and were not required

Volume 11, Number 1, Spring 2009 
to answer comprehension questions, write book reports, or fulfil the requirements of the ubiquitous generic novel study. Still, many of my students were not moving forward with books in ways I expected and recognised. Was I still in the way, in ways I myself could not see? Were my students refusing to recognise their opportunity to progress, and standing in their own way? Or were there other things in the way that prevented them from taking to the open road?

My questions about my teaching led me to the explanations provided by the discourse theory of James Gee. According to Gee (1996), discourses are: ...ways of behaving, interacting, valuing, thinking, believing, speaking, and often reading and writing that are accepted as instantiations of particular roles (or 'types of people') by specific groups of people... They are, thus, always and everywhere social and products of social histories. (p. viii)

Discourses, then, provide people with recognizable ways of being and acting that identify them as belonging to a group. When I viewed my students through the lens of this theory, it became evident to me that through my teaching, I had little understanding of or access to the discursive identities my students had been constructing Moreover, it also became evident to me that I myself was in the process of constructing and enacting my own discursive identities, and that what looked like normative behaviour to me was a construction that did not transfer readily to other discourses (Gee, 1996).

In the process of exploring discourse theory I came to understand that my students were positioned and were positioning themselves in three major discourses as they came to school. First, I saw my students placed in a discourse of Western childhood, one that constructed them as innocent, innately good, loving, and loveable. The school in which I 
taught served solidly middle-class children in an area that was almost exclusively white and Christian. The children were well fed and cared for, and their upbringing was supported by the twin pillars of humanism and materialism. My students believed, for the most part, that they could be and have anything they wanted.

Secondly, my students were constructing a gendered identity for themselves both in the classroom and on the playground. This identity work did not start at school; it is a task that was handed to these children the moment they were born and their gender was announced. My students conducted category maintenance in this binomial gender discourse seriously and continuously alongside anything else that happened at school (Davies, 1989; 1993).

Thirdly, I saw that my students and I had an identity in a pedagogical discourse that affected their responses to anything I introduced or expected. When they were with me they were doing school, and doing school involves rules and expectations that are part of the institution and are carried out by all its members. Although I at times deplored the repressive nature of pedagogical discourse as it was enacted in my school, I relied on its effects to keep my students in their seats and their pencils moving when nothing else was working.

Once I understood something of the discursive work my students and I were doing in the classroom, I began to see that it wasn't only book reports that stood in the way of the literate lives I envisioned for my students. When I freed my students from some aspects of pedagogical discourse, it did not make them free to be what they wanted in school. My teaching and their learning were governed by discourse: invisible, normative, and gargantuan. 
My understanding of discourse theory changed my teaching. I now wanted to make visible the system of rules and expectations that governed all of our behaviour in the classroom; to question the common sense and normative laws that we all followed. One of the first things I did was to take the advice of Freebody, Luke and Gilbert (1991) and organise some of my books into text sets. I looked for texts that surveyed common themes from alternate perspectives, that argued with each other, and that represented points of view that violated common-sense expectations of the discursive identities we owned.

One of my text sets deals with the issues of war (Appendix 1). This is an evolving text set. Texts have made their way in and out of the set according to the interests and needs of my students and the resources I discover. I introduce it here because it caused some furor in my classroom one year. The story of the controversy it engendered is the story of discursive conflict, and it is instructive in suggesting just how many people and practices are in the way of students' learning.

Lauriana and her sister are the daughters of a professional couple. Lauriana's mother and her grandmother were both teachers, and her father is a physiotherapist (Lauriana is the pseudonym this student chose for herself; except for the author, all the other participants are referred to by pseudonyms as well). Although the children had attended my school for their first years, their parents, dissatisfied with public education in general, had withdrawn them two years before to attend a local private school. In the fall of 2004 both girls returned to my school, and Lauriana entered my grade five and six classroom. Lauriana found some aspects of classroom work a struggle from the beginning, and her confidence in herself as a learner suffered as a result. My class was composed of

Volume 11, Number 1, Spring 2009 
independent and successful students, and Lauriana measured herself against these students and found herself wanting. I raised this issue with her parents during an interview in November after the first set of report cards. Her parents were dismayed, and informed me that no one had ever suggested that their daughter was a below-average student before. I suggested some ways they might be able to help at home, including looking at her weekly dialogue journal with her and encouraging her to think deeply about the books she was reading. Around the same time, shortly after Remembrance Day, I introduced the war text set to the class. Three or four times a week I read one of the texts aloud and we discussed it in the context of the other war texts we had read. The students were free to reread these texts during the day, and to write about them instead of their personal books in their weekly dialogue journals. Our class discussions were wide-ranging and lively, and many students chose to write about these books. Lauriana was one of them, and so each week she took one of the war text set books home with her to write a journal letter.

It became evident that Lauriana was having some serious discussions about these books at her house. The following exchange of journal letters illuminates some of the difficulty:

Jan. 10, 2005

Dear Ms. Van de Kleut

In the book Elisabeth by Claire A. Nivola it makes me happy to see the family get back together. But really, it's not likely for her to find her doll at the end. 
In World War II real families get split up. Real people have a better chance of finding each other. The Nazis were MEAN to people of different cultures. I think it's sad that people had to leave everything just to save their lives.

My Dad dislikes the book because he says it starts to teach kids (like me) how we're different instead of alike. This reminds me of Rose Blanche. My dad disliked that book too. He says we shouldn't put labels on people like Jews, Blacks and other immigrants. I asked him "Why do some people treat other people different?" He said "When we become adults we forget about how we're alike. Instead we talk about our differences."

Yours, Lauriana

Jan. 19, 2005

Dear Lauriana,

I think you are absolutely right. It is not at all likely that the woman would find her doll in another country after so many years...

I agree with your dad, that we should not teach kids that we are different instead of alike. Does your dad dislike what happens in the books, or does he dislike the books themselves? I think it is important to read these books with kids so that they learn from the mistakes of history, and begin to treat each other better. On the playground at school children are already treating each other as if some belong 
and some don't. I hope that if children see what happens when you do this, they will begin to change how they are toward each other, and when they are adults these terrible things will not happen. Do you think things like this happen on the playground?

Yours, Ms. V.

Jan. 26, 2005

Dear Ms. Van de Kleut

I have been enjoying the war box. My dad can't wait until it's over. He doesn't think we should know about dying and war until we're older. You know, the basics.

You are right, it's sort of like The Butter Battle Book. In the book My Harmonica where did the parents go when the boy went to the concentration camp? Did he miss them? Why did the soldier tell him to play? I think the book is sort of sad. Don't you?

Yours, Lauriana. 
In February 2005 we had finished reading and discussing the books in the text set. I asked my students to write about the books one last time. I posted three situations on the board, and asked them to choose one, discuss it in light of one or more of the text set books, and give their own opinion about war. The situations included the state of the Chiapas region after the North American Free Trade Agreement was signed, the decision to bomb Hiroshima, given the prediction of 1,000,000 U.S. deaths resulting from an invasion of Japan, and the involvement of Canada in World War II in light of the Holocaust. I hoped that many students could demonstrate their understanding that questions of war are not easy ones, and that the simplistic anti-war message schools teach children while ignoring the many wars raging around the world was no answer at all. Here is Lauriana's response:

My opinion about war is that we don't need it. If (like it did) Japan wanted our country, we should not have to fight. We should have a vote or something else. Who is Hitler? Everyone in Japan did not like him, neither did Allies. What did he do wrong? Japan I at least don't think they like Hitler. Us Canadians joined the Allies to try and defeat Hitler. Why? Hitler is a what? Is Hitler like Osama Bin Laden?

War is very bad. Who started war Ms. V.? The worst thing is war. Look what happened in Feathers and Fools. Not one creature stayed alive. Because of a peacock that mistook a reed for an arrow. The Children We Remember, the Nazis hated the children because they were Jews. 
I answered my question: Who started war. "Everyone." Japanese, Canadians, Americans, Germans, etc.

Despite Lauriana's significant misconceptions about the participants in World War II, I do not see this piece as an example of deficit. There is evidence here that Lauriana is grappling with some of the questions about the nature of war and the responsibilities of nations.

We left war behind and turned to other areas of interest. The day after the Superbowl I shared with my students an analysis of the commercials shown during the broadcast, broken down by Ruby Clayton, a colleague of mine, into race and gender roles. My students were intrigued and horrified by this list, and asked if they could do one themselves. I invited them to watch one hour of primetime television that weekend and keep track of the commercials they saw. Twenty-six students returned on Monday in various states of excitement over the inequities they saw. The twenty-seventh was Lauriana, and she returned her chart in a sealed envelope along with a letter from her father. 


\section{Black and White People Lauriana}

\begin{tabular}{|c|c|}
\hline Black People on T.V. commercials & On a T.V. commercial White people \\
\hline $\begin{array}{l}\text { 1. Act dumb always have the wrong } \\
\text { thing too lazy to cook } \\
\text { dinner or have a bath } \\
\text { has no answers to } \\
\text { anything The women are } \\
\text { skinny and smell they wear } \\
\text { dumb clothes } 6-10\end{array}$ & $\begin{array}{l}\text { 2. Act smart have the right thing make } \\
\qquad 100,000,000 \text { dollars } \\
\text { a week men get women } \\
\text { that are famous, they } \\
\text { are smart, strong, very } \\
\text { talented The women are } \\
\text { beautiful and wear nice } \\
\text { clothes } 9-10\end{array}$ \\
\hline
\end{tabular}

There was a commercial about medication and the black guy has the wrong thing and the white guy has the right thing, the black woman has bad-tasting food, but the white woman has a better-tasting food that her kids will eat.

Feb. 14/05

Dear Mrs. Van de Kleut:

This project really confuses me. Bigoted, stereotypic profiling based on race, has never been discussed, or even thought of in Lauriana's mind. It is difficult for 
me to understand why this negative, discriminatory message would be taught to 10 year old kids. Now, thanks to her liberal education, she thinks there are major differences between black and white people. Until now, they were all the same. It was challenging enough for me to swallow the pro-Japanese/anti-American message regarding the bombing of Hiroshima. This was one event 'out of context' of a very large, complex picture. It's not a simple anti-war message (typical of left-wing liberal thinking).

Then we struggled through the German/anti-Semitic message. I've experienced a great deal of explanation to a 10 year old who cannot possibly grasp such complex issues. She never knew any differences from Germans to Jews, from Japanese to now black people.

Black TV is a commonplace form of entertainment in our world. Lauriana asked me if they really are dumb, lazy, dirty, etc. (look what she wrote). Where does this kind of thinking come from--apparently from the classroom? Where else could she hear this kind of talk?

It should not be difficult to understand why I'm confused. Fortunately our 12 year old never received this form of education in grade 5 , and still sees people as equal regardless of their race or heritage. In fact, she recently said that she wished she knew someone from Japan. When informed her next door neighbour for all her 12 years was $100 \%$ Japanese, she was dumbfounded. She saw no visible differences. Imagine that.

Help me out on this one. 
Thanks,

M.L.

Four days later I sent the following response to Lauriana's father:

Feb. 20, 2005

Dear Mr. L.

It is unfortunate that Lauriana did not understand last week's assignment, and that she did not ask any questions of clarification. The assignment was to watch one hour of prime-time television, and to note in chart form what each population group did and had. The rest of the students in the class turned in charts that noted that white men 'work out' or 'are doctors', while white women 'have wardrobe disasters' or 'dye their hair'. Racist slurs such as the ones Lauriana recorded were never taught, condoned, or asked for, nor did any other student record them. The point of the assignment was for the students to practice critical literacy as they watched commercials, so that they noticed, for example, that white men occupied powerful roles, and black men were underrepresented. Once they had an opportunity to collect this data, we could discuss why such commercials were biased. Critical literacy assignments such as these are required by government curriculum in the junior grades.

Assignments such as these rest on the belief that human beings are different but 
equal, and that inequalities in our society need to be recognized and addressed. Whether or not students acknowledge that people are different, the commercials they are exposed to when they watch television present a world that is unequal, unfair, and unjust. It is important that such messages be countered, since they shape the perspective of the world that our children absorb. This is the view of our Ministry of Education, and it is one which I share.

The books on war that Lauriana brought home to write about were chosen by her. They were not presented in the classroom as statements of fact, but, rather, as different perspectives on a subject. The presentation of different perspectives encourages children to see issues in their complexity, and not as easily-solved societal problems. If you presented a differing viewpoint to these texts as Lauriana chose them, then you have encouraged her to be critical about the texts she encounters--which was the point of the media literacy assignment. When I asked Lauriana why she continued to choose these texts despite your disapproval, she stated that she liked writing about them. I can only conclude that Lauriana was curious about these situations, and valued both your explanations and my responses to her letters.

Thank you for bringing to my attention the fact that Lauriana did not understand the media literacy assignment. In the future, I will endeavour to check her understanding of such assignments, so that these misunderstandings can be avoided. 
Yours truly,

Ms. Geraldine Van de

Kleut

When I showed the letters to my administrators, they asked for proof in the curriculum documents that what I had asked the students to do could be construed as a requirement. They were convinced, and fully supported my response. I sent it to Lauriana's father, and received a response the next day. He returned my letter to me with one part of a sentence highlighted--"never taught, condoned, or asked for, nor did any other student record them.'--and a note written at the bottom:

Thank you for your explanation and comments. This is one of those issues that will continue to 'mystify' me. I asked Lauriana where she heard these 'racial slurs', and I only have her response to depend upon. Perhaps you could ask her yourself. I know how we speak at home, and how her friends speak (who are in her class). What more can I say? It's the first time I've heard these comments from Lauriana. M.L.

A few weeks later I contacted Lauriana's father and asked him if I could use the letter in an article about teaching. He agreed, and his ready response and enthusiasm indicated that first, he did not see his letter as offensive, and second, that he saw me as a victim of government curriculum. He informed me that he had been in contact with a professor of education at the local university, who was an old friend, and had received a 
supportive email in response. Professor M. has published several articles which express a critical view of social justice teaching. In Professor M's view, the purpose of social studies teaching is to inculcate in students such virtues as cooperation, leadership, respect, trust, and obedience. According to Lauriana's father, both he and Professor M. agreed that what I was being made to teach was a big-city curriculum that did not fit our local context.

Lauriana's story is a complex one, involving all the stakeholders in our public education system. From the perspective of discourse theory and in the context of this story, my father's rallying cry for teachers, "Give them the books and get out of their way," has turned into my own plaintive question: Out of whose way shall I get?

I have given Lauriana the books, the best ones at my disposal, in order to encourage thought about complex issues. Clearly, she has taken up my invitation to think along with me. Despite her misunderstandings and confusions, she is still choosing to write about war when she could have been writing about Klikitat Street in the Cleary books that were her daily fare at that time. Is she doing so in order to please me? Am I standing in the way of her development as a reader?

What is Lauriana's motivation for bringing home books that upset and disturb her father? She may be using the books I have provided to differentiate herself from her father and his view of her. In that case, I am providing intellectual tools with which she can fight an emotional battle. Both Lauriana and I feel the effects of her father's disapproval. When I read The Friendship (Taylor, 1987) aloud to the class, Lauriana was the first to ask for the book when I was done. She was drawn to this story of racism in the southern U.S. and wanted to reread it. I handed the book to her, saying, "Your father 
won't like it." She hesitated, and handed it back. "I'd better not read it," she said, "But I just wish my father liked these books." I do not find it easy to determine whether I am practicing prevention or protection here, nor whether I ought to be practicing either. In this incident at least, I am standing in my own way.

Evidently, Lauriana's father wants the best for his daughter, and sees his role as protecting and nurturing her innocence. His assertion that children naturally see no differences between people in the world is shared by many. He does not see himself as occupying a place of power and privilege that maintains itself by keeping power and privilege away from others. He does not acknowledge that the inequities portrayed on television may be forming Lauriana's view of the world to her own detriment and the detriment of those with whom she shares the world, and that a critical analysis of these inequities is a necessity for democratic citizenship. Perhaps he would not even acknowledge that television does portray such inequities. Does he, ultimately, have the right to assert the maintenance of Lauriana's innocence in opposition to my admittedly minority view of the role of education? After all, few teachers in my school believe it is necessary to teach children to be critically literate. Shall I give Lauriana the books her father prefers, and get out of his way?

My letter of response to Lauriana's father implicates me in ways that make me distinctly uncomfortable. Never before in my career have I hidden behind curriculum. Government curriculum has been no friend of mine. Yet, the Ontario government has recently published an Expert Panel Report on Literacy (2004), and it proposes that children be taught critical literacy. In my letter I have expediently aligned myself on the side of might, which has only accidentally, momentarily, and despite itself become right.

Volume 11, Number 1, Spring 2009 
What does it say about me that I have allowed myself to be seen as getting out of the way of curriculum?

My local university sends me teacher candidates to supervise, and they are taught by professors of education such as Professor M. Evidently, he is seen by at least one member of my school's community as an authority on this kind of issue. His belief that the purpose of social studies is to maintain the social order in Canada and encourage respect and obedience influences class after class of teachers and the surrounding community. Is he in my way, or am I in his? Since I arrived at this dilemma by giving Lauriana the books, would he suggest that they were the wrong books, or that she is reacting wrongly to them?

It is clear to me that these are all discursive questions. Professor M. and Lauriana's father share a discourse of childhood that seeks to shelter children from controversial issues and protect their innocence. They also share a political conservatism, which holds that differences make no difference, and merit, like profitability, will create its own opportunity. My administrators share a pedagogical discourse that sees a hierarchy of authority culminating in government-issued curriculum. I myself bring a nexus of discursive identities (Wenger, 1998) into the classroom: liberal, feminist, teacher, social justice advocate, critical thinker, researcher. All these discourses, including the ones in which my students have identities, jostle for position in the classroom. No matter where I stand in the classroom, I am positioned in discourse. No matter where I stand in the classroom -- which after all this I can hardly call mine -- I am in someone's way. 
Nevertheless, it does not follow that there is no way to choose. My integrity as a teacher rests on two ethical principles as stated by Gee (1994):

That something would harm someone else (deprive them of what they or the society they are in view as "goods") is always a good reason (though perhaps not a sufficient reason) not to do it. (p. 292)

One always has the ethical obligation to try to explicate (render overt and conscious) any practice that there is reason to believe advantages oneself or one's group over other people or other groups. (p. 293)

Most of my significant teaching decisions, including my classroom discussion of war and of the commercials shown during the Superbowl, arise from these two principles. When I work with students in the classroom and on the playground, I am conscious that not only does discourse shape us, but we carry out the work of discourse. "This is what you are doing," I say to my students. "Is this who you want to be?" As often as I can, I turn these words on myself.

However, explicating discourse with students cannot be my only task. I represent the institution of school to the parents of my students and to a larger community. This institution has graduated generations of students who believe they possess the right answers as taught by my institution. While these students have learned the scientific method, the discovery of the Americas by Columbus, the essay form, and how to "see Spot run," they have also learned how school is done and what constitutes curriculum. To those who have never learned how to be critically literate, critical literacy, especially when it emanates from a representative of the school, looks like a colonizing force.

Volume 11, Number 1, Spring 2009 
The practice of pedagogy has been, traditionally and historically, to maintain power and authority over knowledge. Lauriana's father understands this: he has twice told me that he is old-fashioned, and in any case where there is an issue with school he fully supports the school. There is no contradiction in his position: when I behave as a traditional pedagogue, he supports my authority; when I cross discursive borders, he becomes the border patrol. Ironically, my reaction to this is to hide behind the practice of pedagogy by appealing to curriculum. This is what I am doing. And this is not who I want to be.

If I accept that my role is not only to explicate discourse for my students and myself, but to also undo the effects of school and schooling in the wider community, I have to consciously give up the claims of power and authority over knowledge that schools have made. Although traditional, these claims are tenuous; any one who has gone to school has participated in the complex and unstable process whereby power is distributed in pedagogical discourses (Foucault, 1990). The story of Lauriana, her father, and me is also the story of power changing hands.I do not have to claim all power on behalf of the institution to know that I use it to create protected spaces for my students and me. I cannot claim all power if critical literacy will ever be understood by the school community.

I also have to acknowledge the multiple truths of discursive positions and the multiple harms that they do, both to my students and to their parents. At the same time, I have to stand by the integrity of my teaching decisions when they are made on the borders of discourse, without retreating back to fortresses from which they can be defended. 
I will continue to put the books in the hands of my students, and we will continue to discuss that which stands in our way and in the way of others. And I will continue to engage my own discomfort as well as incurring that of students, parents, administrators, and educational leaders. Perhaps in that multiplicity of discourses that makes up a classroom we can learn to meet each other without attack or defense, recognizing each other's claims on truth while maintaining our own integrity.

\section{REFERENCES}

Davies, B. (1989). Frogs and snails and feminist tales: Preschool children and gender. North Sydney, Australia: Allen and Unwin.

Davies, B. (1993). Shards of glass: Children reading and writing beyond gendered identities. Cresskill, NJ: Hampton.

Expert Panel on Literacy in Grades 4 to 6 in Ontario. (2004). Literacy for learning: Report of the expert panel on literacy in Grades 4 to 6 in Ontario. Toronto: Ontario Ministry of Education.

Foucault, M. (1990). The History of sexuality: An introduction. Vol. 1. (R. Hurley, Trans.). New York: Vintage. (original work published 1976).

Freebody, P., Luke, A., \& Gilbert, P. (1991). Reading positions and practices in the classroom. Curriculum Inquiry, 21, 435-457.

Gee, J.P. (1994). Postmodernism and literacies. In C. Lankshear \& P. McLaren (Eds.), Critical literacy: Politics, praxis and the postmodern (pp. 271-293). New York: SUNY. 
Gee, J.P. (1996). Social linguistics and literacies: Ideology in discourses (2nd ed.).

London: Routledge.

Taylor, M. D. (1987). The friendship. New York: Scholastic.

Wenger, E. (1998). Communities of practice: Learning, meaning, and identity.

Cambridge: Cambridge University. 


\section{WAR TEXT SET}

Geraldine Van de Kleut_ger.vandekleut@gmail.com

\section{Allegories of War}

Bunting, E. (1989). Terrible Things: An Allegory of the Holocaust. Philadelphia, PA: Jewish Publication Society.

Dr. Suess. (1984). The Butter Battle Book. New York: Random.

Fox, M. (1996). Feathers and Fools. San Diego, CA: Harcourt.

Sharmat, M. (1975). Walter the Wolf. New York: Holiday.

\section{World War I}

Granfield, L. (1995). In Flanders Fields: The Story of the Poem by John McCrae. Toronto, ON: Stoddart.

\section{Japanese/American Conflict}

Dejong, M. (1956). The House of Sixty Fathers. New York: Harper \& Row.

Morimoto, J. (1990). My Hiroshima. New York: Viking.

Say, A. (1982). The Bicycle Man. Oakland,CA: Parnassus.

Tsuchiya, Y. (1997). Faithful Elephants: A True Story of Animals, People and War. Boston: Houghton Mifflin.

\section{The Holocaust}

Abells, C. B. (1986). The Children We Remember. New York: Greenwillow.

Wild, M. (1991). A Time For Toys. Toronto: Kids Can.

Volume 11, Number 1, Spring 2009 


\section{$\underline{\text { Refugees }}$}

Bunting, E. (1988). How Many Days To America: A Thanksgiving Story. New York: Houghton Mifflin.

Nivola, C. (1997). Elisabeth. New York: Farrar Strauss Giroux.

Trottier, M. (2000). Little Dog Moon. Toronto,ON: Stoddart.

\section{The Technology of War}

Begarnie, L. (1987). Fighters, Choppers, and Bombers. New York: Scholastic.

Taylor, M. (1988). Aircraft Carriers. New York: Scholastic.

\section{The Justice of War}

Subcomandante Marcos. (2002). Prayers for a Dignified Life: A Letter to Schoolchildren About the Zapatista Uprising. In B. Bigelow and B.Peterson (Eds.), Rethinking Globalization: Teaching For Justice in an Unjust World (pp. 321-322).

Milwaukee, WI: Rethinking Schools. 